Studia Slavica Savariensia 2016. 1-2. 108-112

DOI: $10.17668 /$ SSS.2016.1-2.108

\author{
Dudás Előd \\ (Budimpešta, Mađarska)
}

\title{
MAĐARSKI UTJECAJ NA RAZVOJ KAJKAVSKE GRAFIJE
}

\begin{abstract}
This article presents the historical development of Kajkavian Croatian spelling in the second half of the 16th century. It focuses on graphemes not in the Latin alphabet whose representation posed a major problem for the first writers of Kajkavian Croatian. It discusses the Hungarian influence of individual graphemes in the first three books of the Kajkavian Croatian literary language.
\end{abstract}

Keywords: development of Kajkavian Croatian spelling, linguistic contact, Hungarian influence, consonants

\section{Uvod}

Povijest hrvatske grafije je jako zanimljiva i dinamična, puna promjena $\mathrm{i}$ različitih utjecaja. Možemo reći da važi za jednu od najzanimljivijih na srednjoeuropskom prostoru, mada su se i grafije drugih srednjoeuropskih naroda razvijale i mijenjale također pod utjecajem različitih tokova. Možemo se složiti s Lászlom Hadrovicsem koji kaže da hrvatska grafija ,,nije organički povezana zgrada nego mukom sastavljeni mozaik" [moj prijevod sa njemačkog, E.D.] (HADROVICS 1994: 8).

U Hrvata je bilo u uporabi više pisama: najprije, od početka pismenosti glagoljica, zatim ćirilica/bosančica, dok se u 14. stoljeću pojavljuje i latinica. Prvi hrvatski tekst koji je pisan latinicom jest Red i zakon sestara dominikanki u Zadru iz 1345 g. Iz istog doba imamo još i Šibensku molitvu, ali se latinica proširila tek tijekom 15. stoljeća (VINCE 1978: 72).

\section{Dvojna tradicija latinske grafije kod Hrvata}

$\mathrm{Na}$ razvoj latinice su na srednjoeuropskom prostoru utjecali crkva i izgovor određenih latinskih glasova (HADROVICS 1951: 165). Što se tiče povijesti latinice u Hrvata, možemo vidjeti da postoje dvije tradicije, vezane uz određeno područje, koje su utjecale na razvoj grafije na različiti način. Dvojna je tradicija sačuvana sve do nastupa Ljudevita Gaja u 19. stoljeću, mada su i prije postojali pokušaji reformiranja hrvatske grafije (usp. HADROVICS 1966). U Primorju, Dalmaciji i na otocima očit je talijanski utjecaj, što je sasvim razumljivo, jer su ova područja bila $\mathrm{u}$ neposrednome dodiru $\mathrm{s}$ Talijanima i Mletačkom Republikom kroz stoljeća. Na ovom području visoko 
je svećenstvo bilo talijanskega podrijetla, dok su niži svećenici svi bili hrvatskog porijekla, mada su svi dobro znali i talijanski pored svog materinskog jezika. (HADROVICS 1994: 9). Sve to je utjecalo na razvoj latinice, što se da vidjeti iz latinskoga suglasničkog skupa /-gn-/ > /nj/, npr. lat. regnum $>$ hrv. renjum; iz latinskog suglasničkog skupa /-sc-/ $>/ \check{\mathrm{s}} /$, npr. lat. descendo > hrv. dešendo (HADROVICS 1994: 9).

Tradicija je bila sasvim drugačija na sjevernom dijelu Hrvatske, zapravo na području Zagrebačke biskupije (osnovao ju je 1094 g. kralj Sveti Ladislav), gdje vidimo utjecaj mađarskog izgovora latinskih glasova. U srednjovjekovnom mađarskom jeziku su lat. /s/ izgovarali kao [š], a u međusamoglasničkom položaju kao [ž], npr. lat. sanctus $>$ hrv. šanktuš, lat. rosa > hrv. roža. Ovaj su način izgovora latinskog /s/ mađarski istraživači obrazlagali sjevernotalijanskim ili njemačkim utjecajem (BALÁZS 1989: 121; KNIEZSA 1952: 69). Izgovor latinskog/s/ prema mađarskoj tradiciji bio je proširen na cijelom području Zagrebačke biskupije. Poznata je i činjenica da Zagrebačka je biskupija bila pod nadzorom Ostrogonske, kasnije Kaločke nadbiskupije, što je značilo da su i liturgičke knjige stizale do Hrvata mađarskim posredovanjem. Time je također bio osiguran utjecaj srednjovjekovnog mađarskog latiniteta. Naravno, ne smijemo zaboraviti ni utjecaj grafije mađarske kraljevske kancelarije. Zvali su je kancelarijska grafija i upotrebljavali je od 11. do 15. stoljeća. Ova se grafija mijenjala gotovo u svakom stoljeću. Grafemi te grafije stizali su i do Hrvata uz pomoć liturgičkih knjiga i zbornika.

Najveću je teškoću predstavljalo označavanje onih glasova koji ne postoje u latinskome jeziku. Ovu su teškoću rješavali na različite načine, npr. uporabom dijakritičkih znakova ili kombinacijama više slova (KOROMPAY 2005: 281). Budući da i hrvatski i mađarski jezik imaju zajedničke glasove koji ne postoje u latinskom jeziku, najjači mađarski utjecaj možemo očekivati u njihovu označavanju. Zbog tijesnih i intenzivnih dodira između Hrvata i Mađara kroz cijeli srednji vijek čini se sasvim razumljivim da su slijedili mađarski način označavanja pojedinih glasova.

\section{Kajkavski književni jezik i grafija}

Početke kajkavskog književnog jezika nalazimo u drugoj polovici 16 . stoljeća. Prva je tiskana knjiga na kajkavskom jeziku bila prijevod poznatog zakonika Istvána Werbőczya. Prijevod je djelo varaždinskog bilježnika Ivana Pergošića. Objelodanjen je bio 1574. g. u Nedelišću. Pored Pergošića imamo još jednog pisca iz ovog razdoblja, Antuna Vramca, koji je 1578. g. izdao jednu kroniku svijeta. Nakon te knjige je sastavio i zbirku propovijedi koja je bila objelodanjena 1586. g. pod naslovom Postilla.

Dosad su o razvoju kajkvske grafije najviše pisali Tomo Maretić i Antun Šojat. Tomo Maretić (1889) je u svojem poznatome djelu o povijesnom razvoju latinske grafije kod Hrvata dao je kratak pregled i o razvoju kajkavske grafije 
kod pojedinih pisaca. Antun Šojat (1970) se u svojoj raspravi bavio početcima kajkavske grafije, zapravo onim razdobljem njezinog razvoja koje jest predmet i našeg sljedećeg istraživanja. Mađarski utjecaj na kajkavsku grafiju obrazlaže ovako: ,Vjekovna povezanost s Mađarima, odvojenost, politička i stvarna, od dalmatinskih Hrvata i utjecaja talijanske kulture, odbojnost prema njemačkoj kulturnoj sferi, reprezentiranoj politikom carske Austrije, upućuju prve kajkavske pisce na široko otvaranje vrata mađarskom utjecaju, pa su oni, u tom smislu, prihvatili i označivanje svojih glasova grafemima i načinom bilježenja paralelnih ili sličnih mađarskih glasova." (ŠOJAT 1970: 266).

U sljedećoj ću raspravi potanko predstaviti sve one grafeme u čijoj se uporabi vidi mađarski utjecaj.

\section{Mađarski utjecaj na razvoj kajkavskih grafema}

Za istraživanje mađarskog utjecaja na kajkavsku grafiju glavni izvori bila su mi prva tri izdanja kajkavskog književnog jezika. Kajkavska se grafija oblikovala u prvim tiskanim knjigama, što znači da kasnije nije doživjela veće promjene. Način pisanja prvih autora bio je uzor i za pisce 17., čak i 18. stoljeća, a u međuvremenu je dolazilo samo do manjih preciziranja pri uporabi pojedinih grafema. Mađarski se utjecaj vidi po uporabi grafema u označavanju glasova $c, \check{c}, l j, n j, s, \breve{s}$ i $\check{z}$. Predstavljam grafeme za označavanje spomenutih glasova iz svih triju tiskanih knjiga 16. stoljeća po pojedinim izdanjima.

\section{Preglednica grafema}

\begin{tabular}{|c|c|c|c|}
\hline & Pergošić, 1574. & Vramec, 1578. & Vramec, 1586. \\
\hline$/ \mathbf{c} /$ & $\mathrm{cz}, \mathrm{c}$ & $\mathrm{cZ}$ & $\mathrm{cZ}$ \\
\hline$/ \check{\mathbf{c}} /$ & ch & ch & ch \\
\hline$/ \mathbf{l j} /$ & ly & & \\
\hline$/ \mathbf{n j} /$ & ny & ni & ni \\
\hline$/ \check{\mathbf{s}} /$ & $\begin{array}{l}\int, \quad \int \Gamma \quad-\quad u \\
\text { međusamoglasničkom } \\
\text { položaju }\end{array}$ & $\begin{array}{l}\int, \quad \mathrm{C} \quad-\quad \mathrm{u} \\
\text { međusamoglasničkom } \\
\text { položaju, s }\end{array}$ & $\begin{array}{l}\int, \quad \int \Gamma \quad-\quad u \\
\text { međusamoglasničkom } \\
\text { položaju, s }\end{array}$ \\
\hline$/ \mathbf{s} /$ & $\mathrm{sz}, \beta$ & 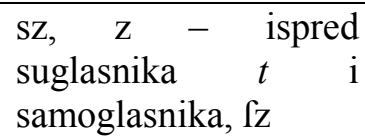 & 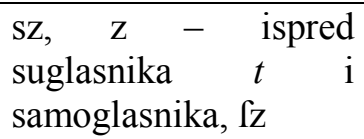 \\
\hline $\mid \check{\mathbf{z}} /$ & $\int$ & $\begin{array}{l}\int, \text { sh - na početku } \\
\text { riječi, s }\end{array}$ & $\begin{array}{l}\int, \text { sh }- \text { na početku } \\
\text { riječi, s }\end{array}$ \\
\hline
\end{tabular}


Grafem $c z$ je jedan od najstarijih slova mađarske grafije koji se prvi put pojavljuje oko 1430. g. i potječe iz češke grafije Jana Husa (KNIEZSA 1959: 7). U mađarskoj je grafiji bio u uporabi do 1922. g. Grafem $c$ pojavljuje se već i u određenim poveljama iz 11. stoljeća, ali se širi tek tijekom 20 . stoljeća i još ga i dan-danas upotrebljavamo.

Označavanje glasa $\breve{c}$ bilo je jedinstveno u prvim kajkavskim knjigama uporabom grafema ch koji je mađarska grafija imala već u 11. stoljeću, a širi se tek s katoličkom grafijom u 16 . stoljeću.

Grafem ly i ny nalazimo isključivo u Pergošićevu prijevodu. Oba su iz 13. stoljeća i još i danas ih upotrebljavamo u suvremenoj mađarskoj grafiji (KNIEZSA 1959: 34).

Među grafemima za označavanje glasa $\check{s}$ mađarski utjecaj odražava jedino slovo $s$ koje se prvi put pojavljuje u 11. stoljeću i još i danas je u uporabi. Uporabu drugih grafema možemo obrazlagati njemačkim utjecajem.

U uporabi grafema za označavanje glasa $s$, slova $s z$ i fz odražavaju mađarski utjecaj. Posljednje se pak pojavljuje isključivo u Vramčevim knjigama. Oba slova potječu iz protestantskih grafija 16 . stoljeća. Slovo $s z$ se prvi put pojavljuje u grafiji Jánosa Sylvestera (KNIEZSA 1959: 34), dok je slovo $f z$ iz grafije Gáspára Heltaia iz šezdesetih godina 16. stoljeća (KNIEZSA 1959: 18). Osim toga, možemo dodati da su i grafem $z$ upotrebljavali u mađarskoj grafiji od 11. stoljeća za označavanje glasa $s$ (KNIEZSA 1959: 6).

Označavanje glasa $\check{z}$ odražava mađarski utjecaj jedino u slučaju slova $s$ koje su prvi put upotrijebili za to 1549 . g. u knjizi Ortographia Ungarica Mátyása Dévaia Bíróa.

\section{Zaključak}

U raspravi sam predstavio mađarski utjecaj na razvoj kajkavske grafije u 16 . stoljeću. Ovim kratkim pregledom pokazao sam da je mađarski utjecaj vidljiv ne samo u posuđenicama i prevedenicama, nego i kod pojedinih grafema. Temeljitije istraživanje ovog područja bi svakako obogatilo naše znanje o mađarsko-hrvatskim jezičnim vezama, te stoga predstavlja još jedan u nizu jezikoslovnih izazova. Pored toga možemo ukazati i na uporedne pojave $u$ razvoju grafije prekomursko-slovenskog književnog jezika (up. DUDÁS 2012) i gradišćanskog književnog jezika. Potonji je temeljitije predstavio László Hadrovics (1974: 46-53) u svojoj opsežnoj monografiji o gradišćanskohrvatskom književnom jeziku 18. i 19. stoljeća. Sve to nam kazuje da su se grafije ovih regionalnih književnih jezika razvijale pod utjecajem pojedinih mađarskih grafija kroz stoljeća. Naravno, ima i razlike u njihovu razvoju te bi bio zanimljiv zadatak predstaviti zajedničke točke razvoja a tako izvedena poredbena analiza bi svakako pokazala zanimljive rezultate. 


\section{Literatura}

BALÁZS 1989 = BALÁZS J. A latin a Duna-tájon // Nyelvünk a Duna-tájon. Ur. János Balázs. Budapest, 1989. 95-140.

DUDÁS 2012 = DUDÁS E. Primerjalni zgodovinski razvoj prekmurskega črkopisa // Jezikoslovni zapiski, 2012. № 2. 149-165.

HADROVICS $1951=$ HADROVICS L. A XVI. századi protestáns horvát nyomtatványok helyesírása // A Magyar Tudományos Akadémia Nyelv- és Irodalomtudományi Osztályának Közleményei, 1951. 164-172.

HADROVICS 1966 = HADROVICS L. Pokušaj reforme latiničkog pravopisa 1785 godine // Beogradski universitet. Anali filološkog fakulteta, 1966. № 5. 268-272.

HADROVICS 1974 = HADROVICS L. Schrifftum und Sprache der burgenländischen Kroaten im 18. und 19. Jahrhundert. Budapest, 1974.

HADROVICS $1994=$ HADROVICS L. Zur Geschichte der kroatischen Rechtschreibung im XVIII. Jahrhundert // Segédkőnyv a szlavisztikai szemináriumi gyakorlatokhoz. Hadrovics László válogatott írásaiból. Ur. István Nyomárkay. Budapest, 1994. 7-40.

KNIEZSA 1952 = KNIEZSA I. A magyar helyesírás története. Budapest, 1952.

KNIEZSA 1959 = KNIEZSA I. A magyar helyesírás története: második, javított kiadás. Budapest, 1959.

KOROMPAY 2005 = KOROMPAY K. Helyesírás-tőrténet // Magyar nyelvtőrténet. Ur. Jenő Kiss, Ferenc Pusztai. Budapest, 2005.

MARETIĆ 1889 = MARETIĆ T. Istorija hrvatskoga pravopisa latinskijem slovima. Zagreb, 1889.

S̆OJAT 1970 = ŠOJAT A. Pravopis stare kajkavske književnosti // Filologija, 1970. № 6. 265-282.

VINCE 1978 = VINCE Z. Putovima hrvatskoga književnog jezika. Zagreb, 1978. 